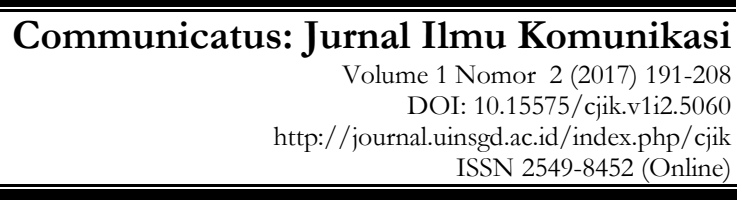

\title{
Komunikasi Nonverbal Jamaah Tabligh
}

\author{
Imron Rosyidi $^{1^{*}}$, Encep Dulwahab ${ }^{2 *}$ \\ ${ }^{12}$ UIN Sunan Gunung Djati Bandung \\ “imronrasyidi@yahoo.com
}

\begin{abstract}
One organization that is fast and has a large number of worshipers is the Tabligh worshipers. Tabligh congregation when communicating not only verbally, but also nonverbally is a characteristic and identity, both in the form of clothes, caps, beards and perfumes. It also includes ways to eat and shake hands that have their own characteristics and are different from other worshipers. This study uses a qualitative approach to the phenomenology tradition, and this study aims to find out how the Jama'at Tabligh nonverbal communication. The results of this study indicate that Jamaat Tabligh nonverbal communication has a charge of nonverbal messages that are so attached to each activity and their interactions with fellow worshipers or the community in general. These nonverbal messages are at the same time as a confirmation of a Muslim's identity, which functions as self-control, as a medium to strengthen the brotherhood of fellow Muslims (Ukhuwah Islamiyah), and as a form of glorifying one's fellow Muslims (Ikramul Muslimin). And nonverbal nonverbal communication is a manifestation of his belief as a Muslim who must practice the teachings of Islam and his love for the Prophet.
\end{abstract}

Keywords: communication, nonverbal, congregation tabligh

\begin{abstract}
ABSTRAK
Salah satu organisasi yang cepat dan memiliki jumlah jamaah yang cukup banyak adalah jamaah tabligh. Jamaah Tabligh ketika berkomunikasi tidak hanya verbal, tetapi juga nonverbal yang menjadi ciri khas dan identitasnya, baik dalam bentuk pakaian, peci, jenggot, dan parfum. Termasuk juga cara makan dan cara bersalaman yang memiliki ciri tersendiri dan berbeda dengan jamaah lainnya. Penelitian ini menggunakan pendekatan kualitatif dengan tradisi fenomenologi, dan penelitian ini bertujuan untuk mengetahui bagaimana komunikasi nonverbal Jamaah Tabligh. Hasil penelitian ini menunjukkan bahwa komunikasi nonverbal Jamaah Tabligh memiliki muatan pesan-pesan nonverbal yang begitu melekat pada setiap aktivitas dan interaksinya dengan sesama jamaah atau masyarakat pada umumnya. Pesan-pesan nonverbal ini sekaligus sebagai penegas identitas seorang muslim, yang berfungsi sebagai kontrol diri, sebagai media untuk mempererat persaudaraan sesama umat muslim (Ukhuwah Islamiyah), dan sebagai bentuk sikap memuliakan kepada sesama muslim (Ikramul Muslimin). Dan
\end{abstract}


Imron Rosyidi \& Encep Dulwahab

komunikasi nonverbal nonverbal tersebut merupakan manifestasi akan keyakinannya sebagai muslim yang harus mengamalkan ajaran agama Islam dan kecintaannya pada Rasulullah saw.

Kata kunci : komunikasi, nonverbal, jamaah tabligh

\section{PENDAHULUAN}

Organisasi keagamaan Islam biasanya memiliki perbedaan dalam masalah aqidah, fikih, dan metode dakwah. Anggota organisasi keagamaan tersebut tidak memiliki perbedaan dalam penampilan fisik, kecuali pada kelompok Jamaah Tabligh terdapat perbedaan yang khas, seperti dalam cara berpakaian, mereka biasanya mengenakan jubah atau baju gamis berlengan panjang yang tidak bercorak dan memakai celana panjang di atas mata kaki. Selain itu, ciri khas mereka adalah selalu mengenakan peci yang bentuknya bulat seperti peci haji yang umumnya berwarna putih atau warna lainnya. Mereka juga memiliki kebiasaan memelihara jenggot, di mana ukuran panjang jenggot seorang jamaah mencirikan senioritas atau tingkat loyalitas terhadap kelompok mereka.

Kelompok Jamaah Tabligh memiliki kebiasaan dan cara makan yang berbeda dengan masyarakat pada umumnya yaitu makan bersama-sama pada satu nampan besar dengan menggunakan tangan tanpa menggunakan alat-alat makan seperti piring, sendok dan garpu. Ciri khas lain kelompok ini adalah sikap sederhana dalam kehidupan sehari-hari, seperti dalam kebiasaan makan, berpakaian, tempat tinggal dan sebagainya, walaupun di antara mereka banyak yang berkecukupan dalam materi, akan tetapi pada umumnya tidak menampakkan sikap hidup yang mewah.

Karakteristik kelompok Jamaah Tabligh adalah bersikap ramah dan akrab, karena prinsip mereka dalam melakukan dakwah kepada masyarakat adalah menggunakan pendekatan silaturahmi dan menerapkan ajaran Ikramul Muslimin (selalu memuliakan umat Muslim). Sikap ini tercermin dalam kebiasaan mereka yang selalu memberi senyuman, menyapa dan menyalami orang lain khususnya kepada sesama Muslim. Mereka biasanya berjabat tangan dengan erat, tidak sekedar menempelkan tangan, apabila dilakukan antara sesama kaum pria. Berbeda dengan tata cara bersalaman dengan kaum wanita, mereka menghindari bersentuhan secara langsung.

Jamaah Tabligh memiliki metode dakwah yang khas menggunakan metode khuruj dengan cara keluar secara berkelompok untuk berdakwah menuju suatu tempat, biasanya mereka menginap di masjid selama beberapa hari. Selama berada di lokasi atau masjid mereka melaksanakan ibadah-ibadah wajib dan sunah seperti shalat lima waktu secara berjamaah, shalat sunnah, berdoa, berdzikir, membaca Al-Quran, berdiskusi, bermusyawarah, beritikaf, menyampaikan taushiyah, merencanakan kegiatan dakwah dan amalan-amalan bermanfaat lainnya. Selain melaksanakan amalan-amalan di atas mereka juga beristirahat dan makan di dalam atau area sekitar masjid.

Communicatus: Jurnal Ilmu Komunikasi 1(2) (2017) 191-208 
Metode dakwah Jamaah Tabligh adalah bersilaturahmi dengan masyarakat sekitar masjid dan masyarakat umum dengan mendatangi rumah-rumah warga dan mengajak masyarakat untuk melaksanakan kebaikan dan amal ibadah; khususnya shalat lima waktu secara berjamaah di masjid. Mereka menjadikan masjid sebagai pusat pengembangan dakwah dan mengumpulkan orang-orang di masjid untuk menyampaikan pesan-pesan keagamaan, biasanya mereka membacakan ayat-ayat dan hadits yang bersumber dari buku Fadlaailul a'mal yang berisi keutamaan-keutamaan amal ibadah.

Keberadaan Jamaah Tabligh di tengah masyarakat Indonesia memiliki arti penting dalam kehidupan sosial beragama, dan jika ditinjau dari perspektif komunikasi keberadaan mereka merupakan fenomena komunikasi. Karakteristik yang khas pada mereka sedikit banyak berpengaruh pada pola komunikasi antara mereka dengan umat Islam pada umumnya, setidaknya keberadaan mereka menimbulkan kesan ekslusif, dan muncul pandangan yang miring bahkan negatif yang disebabkan oleh metode dakwah mereka, yaitu mengajak orang secara langsung untuk melaksanakan amalan ibadah, atau faktor lain seperti simbolsimbol nonverbal berupa penampilan fisik yang berbeda dari umat Islam pada umumnya, yang sudah menjadi tradisi Jamaah Tabligh dalam kehidupan seharihari.

Penelitian ini menggunakan metode kualitatif dengan perspektif fenomenologis. Metode penelitian kualitatif berupaya untuk memahami gejalagejala yang sedemikian rupa dan memerlukan ketajaman dalam menggali, mengidentifikasi, dan menginterpretasi suatu fenomena. Adapun tujuan dari penelitian ini adalah untuk mengetahui pola komunikasi nonverbal pada kelompok Jamaah Tabligh.

\section{HASIL DAN PEMBAHASAN}

Jamaah Tabligh menampilkan simbol-simbol ketika berkomunikasi nonverbal dalam kehidupan sehari-hari. Mereka melakukannya didasari karena mengamalkan sunnah Rasul. Semua simbol-simbol nonverbal yang ditampilkan Jamaah Tabligh merupakan manifestasi ketaatan dan kecintaan seorang muslim kepada Rasulullah saw. Dalam pandangan mereka sunnah Rasul terbagi menjadi tiga, yaitu surab (perkataan, perilaku dan potret), sirah (biografi) dan sarirah (pikir) Nabi Muhammad saw. mereka menampilkan pesan-pesan non verbal tersebut didasari karena kecintaan dan kesetiaan kepadanya.

\section{Kebiasaan Memanjangkan Jenggot}

Memelihara jenggot menjadi kebiasaan anggota Jamaah Tabligh. Memelihara jenggot dengan tujuan mengamalkan sunnah Rasul, dan dapat menjadi kendali untuk dirinya dari melakukan perbuatan-perbuatan yang melanggar syariat agama. Fungsi tersebut tidak akan terjadi pada orang yang memanjangkan jenggotnya untuk alasan mode, gaya atau alasan lainnya.

Tradisi memelihara jenggot berkembang di di kalangan jamaah Tabligh, 
dan menjadi ciri khas penampilan fisik mereka. Artefak ini tampak pada diri mereka mendukung ciri khas lainnya seperti pakaian, peci, parfum dan lain-lain. Berjenggot agak tebal, panjangnya kurang lebih tujuh centimeter ini, jenggot sebetulnya adalah identitas bagi seorang muslim, jadi bukan hanya anggota Jamaah Tabligh yang biasa memelihara jenggot, ada orang muslim selain anggota Jamaah Tabligh yang juga berjenggot, hanya saja hampir setiap anggota Jamaah Tabligh memelihara jenggotnya, termasuk dirinya. Jenggot merupakan artefak bagi seorang muslim.

Anggota Jamaah Tabligh yang berjenggot memiliki korelasi dengan pernyataan Rasulullah saw.: "Panjangkanlah jenggotmu dan cukurlab kumismu, bedakan dirimu dengan orang majusi". Beliau mengatakan bahwa seorang muslim tidak boleh menyerupai orang nonmuslim dalam berbagai aspek, dan seorang muslim tidak dibolehkan mengikuti tradisi-tradisi dan cara-cara orang non muslim, termasuk dalam hal memelihara jenggot. Sebagaimana ditegaskan Al-Fauzan (1999:16), bahwa di antara bentuk kecintaan kepada orang kafir adalah menyerupai mereka dalam tata cara berpakaian, berbicara, dan lain sebagainya. Mengenai hal ini, Rasulullah saw. juga pernah bersabda: "Barang siapa yang menyerupai suatu kaum maka dia adalah sebagian dari mereka". Oleh karena itu, selaku orang muslim jangan sampai menyerupai orang-orang kafir. Menyerupai dalam berbagai aspek, seperti adat dan tradisi, ibadah, simbol, mencukur jenggot, memanjangkan kumis, berbicara dengan bahasa mereka kecuali karena kebutuhan yang mendesak. Termasuk menggunakan pakaian, makan, minum dan lain sebagainya.

Pernyataan Al-Fauzan berangkat dari sabda Rasul yang berhubungan dengan loyalitas seorang Musilm terhadap agamanya yang sarat dengan konteks bangsa dan budaya Arab khususnya dalam hal bahasa. Namun demikian Jamaah Tabligh memiliki pemahaman yang selaras dengan pendapat tersebut dalam beberapa aspek seperti pakaian, cara makan dan jenggot. Jenggot makna jenggot sebagai kendali dan kontrol diri.

Memelihara jenggot dan mencukur kumis seringkali dianggap aneh dan dipandang sebelah mata oleh masyarakat, bahkan seringkali dianggap muslim fundamentalis, seperti dikatakan Mulyana (2000:349-350), bahwa pria muslim berjenggot sering dipersepsi sebagai muslim yang fanatik terhadap ajaran agama, atau seringkali dicap sebagai muslim yang fundamentalis. Memang karakteristik fisik memiliki seperti daya tarik, seperti warna kulit, rambut, kumis, jenggot. Jelas itu semua dapat mengkomunikasikan sesuatu pada orang.

Jamaah Tabligh termasuk kelompok Islam yang mengamalkan tradisi memanjangkan jenggot, tetapi gerakan ini tidak termasuk kelompok fundamentalis Islam, mereka tidak pernah terlibat dalam berbagai macam aktivitas politik. Jamaah Tabligh adalah gerakan paling "aman" di negeri ini. Berdasarkan keterangan pejabat militer tingkat pusat, tidak ada catatan mengenai keterlibatan kelompok ini dalam sebuah gerakan politik terlebih tindakan anarkis.

Orang Indonesia pada umumnya tidak memiliki jenggot, sebagaimana 
bangsa Asia pada umumnya bangsa Asia memiliki struktur tubuh yang berbeda dengan bangsa Arab atau bangsa Barat. Nabi Muhammad saw. bersabda: "Panjangkanlah jenggotmu dan cukurlah kumismu, bedakan dirimu dengan orang majusi."

\section{Memakai Peci dalam Beraktivitas}

Peci memiliki makna yang sama dengan jenggot, sebagai identitas Muslim. Peci yang dimaksud adalah tutup kepala berbentuk bulat atau lonjong, berwarna putih atau warna lainnya, polos atau bermotif. Identitas seorang Muslim lebih ditekankan pada saat melakukan dakwah, mengajak orang-orang untuk melaksanakan amalan-amalan agama seperti shalat berjamaah di masjid, dengan demikian persepsi orang-orang yang diajak tidak keliru terhadap ajakan Jamaah Tabligh tersebut. Dari pernyataan tersebut dapat dipahami bahwa peci dapat menjadi variabel pendukung dalam menjalankan aktivitas dakwah Islam, seorang da'i dituntut untuk menjaga kredibilitas dirinya termasuk dalam berpenampilan.

Peci memiliki arti sebagai ciri orang muslim dan merupakan bukti kecintaannya pada Rasulullah saw.. Dalam menjawab beberapa pertanyaan yang berkaitan dengan simbol-simbol nonverbal Jamaah Tabligh dia hampir selalu menyampaikan alasan sebagai bentuk kecintaannya pada Rasulullah saw.

Peci khas Jamaah Tabligh sebagai simbol yang identik dengan orang shaleh. Memakai peci menimbulkan kesan positif. Peci dapat menjadi kontrol diri dari berbuat maksiat. Orang yang memakai peci dengan didasari keimanan dan keikhlasan akan malu melakukan perbuatan yang tidak pantas dilakukan seorang muslim seperti berjoged.

Peci juga bisa mempengaruhi suasana hati saat beribadah, menurutnya peci dapat menambah kekhusyukan saat melaksanakan shalat. Dengan memakai peci seorang tampak lebih sopan, shalat ibadah menghadap Allah, di dalam Al-Quran dijelaskan agar seorang muslim memakai perhiasan ketika shalat, peci menjadi salah satu perhiasan bagi laki-laki.

Anggota Jamaah Tabligh selalu memakai peci hampir di setiap aktivitas sehari-hari terutama pada saat melaksanakan shalat. Peci menjadi ciri khas kelompok Jamaah Tabligh selain atribut lainnya seperti jubah, baju gamis, jenggot dan parfum tanpa alkohol serta simbol-simbol lainnya.

Ketika berlangsung pengajian atau dalam istilah mereka disebut bayan, sesuatu yang menjadi ciri khas mereka adalah kumpulan orang banyak dengan atribut-atribut khas, di antaranya adalah peci. Pengajian akbar yang dilaksanakan secara rutin setiap malam jumat di Masjid Al-Madinah Antapani Bandung, selalu dihadiri oleh ratusan jamaah dari berbagai wilayah di Jawa Barat.

Pada acara tersebut tampak pemandangan yang tidak ditemui di tempat pengajian lain, diperkirakan lebih dari 800 orang mengikuti acara pengajian dengan megambil tempat duduk merapat ke depan mendekati penceramah, antara satu jamaah dengan jamaah lain saling berdekatan, hampir tidak ada celah antara satu jamaah dengan yang lainnya. Dalam acara tersebut tampak hampir 
semua jamaah memakai peci.

Pemandangan tersebut juga seringkali terlihat pada acara Majelis Dzikir bersama Arifin Ilham, atau Majelis Manajemen Qolbu bersama Abdullah Gymnastiar, tetapi yang membedakan kedua majelis tersebut dengan majelis Jamaah Tabligh adalah pemakaian peci oleh Jamaah Tabligh tidak hanya pada saat berlangsungnya pengajian, tetapi juga pada kehidupan sehari-hari seperti pada saat bekerja dan pada saat bepergian, bahkan salah satu aturan dan tata cara makan Jamaah Tabligh adalah memakai peci.

Jamaah Tabligh selalu memakai peci yang berbentuk bulat atau lonjong dengan warna warna yang bervariasi. Menurut mereka peci merupakan simbol yang merepresentasikan reliligiusitas seorang Muslim, dengan memakai peci seseorang akan kelihatan lebih sopan dan lebih bagus, peci akan menambah penampilan seseorang menjadi lebih rapi. Menurut Jamaah Tabligh pakaian resmi seorang muslim memakai tutup kepala, apapun jenis dan bentuknya.

Bangsa Arab memakai tutup kepala tidak sekedar memakai peci, tetapi juga memakai sorban, bangsa Indonesia biasanya memakai peci hitam atau biasa disebut kopiah. Jamaah Tabligh lebih memilih memakai peci berbentuk bulat atau lonjong atau bentuk-bentuk lainnya, karena dianggap tidak sektarian; tidak merepresentasikan simbol kebangsaan tetapi lebih menitikberatkan pada simbol ke-Islaman.

Peci sebagai pembeda sekaligus sebagai pengingat agar penggunanya senantiasa berperilaku dan berbuat sesuai ajaran agama Islam, peci atau dikalangan pesantren para santri menggunakan kopeah, yang tujuannya ialah membedakan antara santri dengan masyarakat umumnya. Seperti yang diperlihatkan dalam penelitian Rahman (2016) dengan judul Komunikasi Dakwah Pesantren Tradisional. Pembeda antara santri dan masyarakat adalah pada pakaian, salah satunya ialah kopeah untuk santri lelaki.

\section{Memakai Pakaian yang Khas}

Jubah, baju gamis berlengan panjang, celana panjang di atas mata kaki, diyakini oleh Jamaah Tabligh dapat mendukung keberhasilan dakwah. Ada dua jenis pakaian Nabi Muhammad saw., yaitu pakaian sehari-hari dan pakaian untuk turun ke medan perang. Pakaian sehari-hari beliau adalah seperti pakaian bangsa Arab saat ini, yaitu berbentuk jubah, sedangkan pakaian yang digunakan untuk berperang adalah berupa gamis lengan panjang dan celana panjang yang tidak melebihi mata kaki. Pakaian Jamaah Tabligh mengikuti bentuk pakaian Rasulullah untuk ke medan perang, pakaian tersebut dinilai lebih mendukung mobilitas mereka dalam melakukan aktivitas dakwah.

Memakai pakaian seperti yang biasa dipakai oleh anggota Jamaah Tabligh; memakai jubah, gamis atau yang sejenisnya memiliki nilai dakwah. Dakwah adalah mengajak (mendorong) manusia untuk mengikuti kebenaran dan petunjuk, menyeru mereka berbuat kebajikan dan melarang mereka dari perbuatan munkar agar mereka mendapat kebahagiaan di dunia dan di akhirat

Communicatus: Jurnal Ilmu Komunikasi 1(2) (2017) 191-208 
(Mahfudz dalam Rafiudin dan Djaliel, 1997:24).

Dakwah dapat dilakukan dengan berbagai cara sesuai kemampuan, seorang Muslim dapat menyampaikan ajaran Islam secara lisan atau dikenal dengan tabligh. Metode dakwah tersebut termasuk ke dalam dakwah billisan (dakwah menggunakan lisan). Dakwah juga dapat dilakukan dengan berbagai kegiatan yang langsung menyentuh kepada masyarakat, metode tersebut termasuk dakwah bil haal (dakwah menggunakan potensi yang ada). Simbol-simbol nonverbal Jamaah Tabligh menjadi salah satu bentuk dakwah.

Pakaian menjadi identitas seseorang, seorang yang memakai pakaian seperti biasa pada umumnya orang Indonesia, menurutnya tidak ada bedanya dengan orang nonmuslim. Padahal seperti disabdakan Rasulullah "Barangsiapa yang menyerupai suatu kaum, maka dia adalah bagian dari mereka". Atas dasar argumentasi tersebut Jamaah Tabligh memakai gamis dan jubah yang dianggap lebih mengikuti sunnah rasul dan dapat menajdi kendali bagi seorang muslim untuk terhindar dari perbuatan maksiat.

Hal ini berdasarkan ayat Al-Quran surat Al-A'raf ayat 31, Pakailah perbiasanmu ketika melaksanakan shalat (di masjid). Jamaah Tabligh memahami kata "perhiasanmu" dalam ayat tersebut adalah memakai pakaian terbaik yang mereka miliki, yaitu berupa baju gamis lengan panjang, memakai peci, dan memakai minyak wangi.

Jamaah Tabligh memakai gamis dianggap lebih bagus daripada memakai baju biasa, karena model pakaian tersebut dianggap lebih memenuhi ketentuan syariat Islam yang memerintahkan menutup aurat. Model pakaian biasa yang berbentuk kemeja atau kaos dan celana panjang dianggap kurang memenuhi ketentuan menutup aurat, karena hanya membungkus tubuh.

Dalam pandangan jamaah tabligh, belum dikategorikan menutup aurat secara sempurna apabila seorang muslim memakai pakaian biasa. Ada beberapa ketentuan menutup aurat, di antaranya pakaian tidak ketat sehingga menampakkan lekuk bentuk tubuh, tidak transfaran, tidak berwarna tertentu yang menunjukkan identitas atau karakteristik kelompok agama lain, seperti warna kuning kemerah-merahan yang biasa dipakai oleh orang Hindu atau Budha.

Bentuk pakaian seorang muslim tidak boleh menyerupai pakaian orang Yahudi atau Nasrani, bentuk pakaian laki-laki tidak menyerupai pakaian perempuan, sebaliknya bentuk pakaian perempuan juga tidak boleh menyerupai pakaian laki-laki. Pakaian laki-laki tidak boleh terbuat dari bahan sutera.

Seorang muslim melakukan shalat dengan memakai pakaian sehari-hari dianggap telah memenuhi syarat. Tetapi untuk memperoleh keutamaan ibadah dianjurkan untuk memakai pakaian terbaik yang ia miliki, agar menambah kesakralan ibadah tersebut dan menambah nilai estetis. Seperti seorang yang akan menghadap atasan kerja, pimpinan, pejabat pemerintah, atau orang yang dihormati di masyarakat tidak pantas hanya memakai pakaian alakadarnya, karena 
Imron Rosyidi \& Encep Dulwahab

dianggap tidak sopan.

Selain memakai gamis, ada jamaah yang memakai baju khas muslim atau dikenal di masyarakat dengan baju koko atau baju takwa. Jenis baju ini sering dipakai oleh orang Muslim dalam kehidupan sehari-hari ketika melaksanakan shalat, pergi ke masjid, ke majelis ta'lim atau ke acara keagamaan lainnya.

Ada di antara mereka yang tidak berpakaian sebagaimana lazimnya anggota Jamaah Tabligh, tetapi jumlahnya tidak banyak. Mereka memakai baju biasa yaitu kemeja tangan panjang dengan warna polos atau corak tertentu seperti bergaris, kotak-kotak, atau motif lainnya. Walaupun memakai pakaian seperti biasa, ciri khas anggota Jamaah Tabligh akan tetap kelihatan dari simbol-simbol lain yang mereka pakai seperti peci, sandal dan jenggot (bagi orang yang secara genetik memiliki jenggot).

Warna pakaian anggota Jamaah Tabligh biasanya putih atau warna lain yang yang bercorak polos dan tidak menyolok seperti krem, abu-abu, biru, coklat, hitam, hijau dan sebagainya. Warna putih menjadi pilihan utama mereka karena mengikuti apa yang dicontohkan Nabi Muhammad saw., beliau menyukai pakaian yang berwarna putih, dan selalu memakai pakaian yang berwarna putih. Nabi Muhammad saw. adalah tauladan bagi setiap Muslim yang harus diikuti semua gerak dan tingkah lakunya, sehingga dalam cara berpakaianpun umat Muslim harus mengikutinya.

Senioritas kelompok Jamaah Tabligh tidak dapat dilihat dari cara mereka berpakaian dan dari penampilan fisiknya. Ada fenomena seorang yang baru menjadi anggota berpenampilan secara penuh sesuai aturan dan bisa jadi jamaah yang sudah senior mengalami degradasi loyalitas terhadap aturan dalam berpenampilan. Kecuali bagi seorang Amir yang memimpin jamaah atau penceramah yang menyampaikan materi-materi bayan (nasihat-nasihat atau penjelasan-penjelasan), dituntut untuk mengamalkan aturan dan tata cara berpenampilan dan harus memberi contoh. Apabila mereka melanggar aturan akan mendapat teguran karena mereka memiliki tanggung jawab.

Para Jamaah Tabligh yang menggunakan peci dan pakaian yang berbeda, menurut Rizal sebagai bagian dari cultural artifact. Cultural artifact ini merupakan salah satu yang diperhatikan seseorang ketika berkomunikasi, mulai dari bentuk fisik, cara berpakaian, dan konsep diri (Rizal, 2017: 59).

\section{Parfum yang Tidak Beralkohol}

Memakai parfum atau wewangian merupakan tradisi banyak orang di seluruh dunia selama berabad-abad, yang bertujuan untuk menyampaikan pesan. Jamaah Tabligh memiliki tradisi memakai parfum yang tidak mengandung alkohol. Menurut Mulyana (2000:352), kaum pria dianjurkan untuk menggunakan wewangian pada saat mereka melaksanakan shalat Jumat. Orang-orang saling mengoleskan parfum yang tidak beralkohol itu kepada sesamanya, sebagai tanda persaudaraan. Hal ini masih dilakukan sebagian muslim khusunya oleh 
kelompok muslim yang aktif berdakwah dari daerah ke daerah, kota ke kota, dan dari negara ke negara, yang dikenal dengan sebutan Jamaah Tabligh.

Aktivitas dakwah dan kegiatan ta'lim Jamaah Tabligh memiliki karakteristik dan suasana yang berbeda dengan kelompok lain, ketika berlangsung bayan (majelis yang diadakan untuk menerangkan maksud dan tujuan usaha dakwah dan menjelaskan masalah-masalah agama) misalnya, posisi duduk jamaah merapat satu sama lain, hampir tidak ada celah dan jarak di antara mereka.

Dalam situasi seperti ini terkadang muncul aroma tubuh yang kurang sedap, sehingga membutuhkan pengharum. Dengan parfum suasana tempat beraktivitas menjadi harum dan kondusif untuk melaksanakan berbagai kegiatan ibadah seperti shalat berjamaah, bermusyawarah, berdzikir, membaca Al-Quran dan sebagainya.

Rasulullah saw. senang kepada wangi-wangian, para malaikat juga senang kepada wangi-wangian. Dengan memakai parfum Malaikat Rahmat akan turun untuk menyampaikan rahmat Allah kepada hamba-hamba-Nya yang menjaga kebersihan dan menebarkan aroma wangi.

Parfum memiliki nilai positif dan menunjang kesuksesan pergaulan seharihari. Seorang yang tubuhnya wangi akan lebih percaya diri untuk berinteraksi dengan orang lain. Orang akan merasa betah dan senang berdekatan dengan seorang yang beraroma wangi. Bahkan menurutnya aroma wangi tidak saja disukai oleh manusia, tetapi juga disukai oleh para malaikat. Nabi Muhammad saw. pernah mencontohkan perumpamaan berteman dengan seorang yang baik dengan seorang yang membawa minyak wangi.

Aroma tidak sedap dapat mengganggu pelaksanaan shalat berjamaah, sabda Rasul: "Barang siapa yang makan bawang merah, bawang putib, bawang bakung maka ia jangan mendekati masjid". Seorang yang akan pergi ke masjid hendaklah dalam keadaan bersih, tidak membawa bau tidak sedap yang dapat mengganggu orang lain yang berada di dekatnya.

Jamaah Tabligh menekankan anggotanya selalu memakai parfum agar menimbulkan aroma harum, terutama saat berada di masjid, tidak setiap Muslim menyadari bahwa memakai parfum adalah sunnah Rasul, dalam kaitannya dengan aroma tubuh Mulyana (2000:352) menyebutkan kalau bau (aroma) badan memang amat sensitif ketika berkomunikasi dengan orang lain. Terkadang ada orang yang tidak mau berdekatan dengan orang yang memiliki bau badan tidak sedap, bau ketiak, apalagi bau mulut, maka orang akan cenderung menghindarnya. Oleh karena itu, kalau menyadari diri memiliki bau badan yang kurang enak, sebaiknya sebelum pergi ke acara-acara formal yang akan bertemu banyak orang, biasakan menggosok badan dengan sabun mandi agar tidak bau badan lalu menggunakan deodoran, menggosok gigi agar tidak bau mulut, kalaupun sesudah sikat gigi tetap bau maka bisa dengan berkumur-kumur menggunakan cairan pembersih mulut dan pembunuh kuman, lalu mengenakan pakaian bersih dan harum dan mengoleskan parfum, sepatu yang bebas bau dari 
kaos kaki.

Parfum yang mengandung alkohol dalam pandangan Jamaah Tabligh tidak boleh dipakai karena dzatnya yang haram untuk dikonsumsi, dengan demikian haram juga untuk dipakai sebagai bahan campuran parfum. Terlepas dari adanya perbedaan pendapat dalam masalah ini, anggota Kelompok Jamaah Tabligh hanya mau memakai parfum yang bebas alkohol karena didasari oleh keyakinan mereka, dan dengan maksud untuk menghindari terjerumus kepada perbuatan yang diharamkan oleh agama. Sekecil apapun sesuatu yang mengandung unsur ibadah, dalam pandangan mereka tidak boleh dianggap remeh dan tidak boleh ditinggalkan, termasuk memakai wewangian.

Parfum yang dipakai oleh anggota Jamaah Tabligh terdiri dari berbagai macam aroma; sebagian dari aroma tersebut mirip dengan parfum merek-merek terkenal seperti Chanel, Bvulgari, Christian Dior dan sebagainya. Ada pula aroma-aroma alami seperti melati, mawar, seribu bunga Hajar Aswad dan sebagainya.

Para jamaah tabligh tidak terlalu memperhatikan merek parfum-parfum, menurut mereka yang terpenting adalah aromanya yang enak. Mereka memakainya tidak saja pada saat pergi ke masjid tetapi juga dalam menjalankan sehari-hari pun mereka tidak lepas dari minyak wangi, sehingga ketika mereka berada di sekitar orang lain akan segera diketahui keberadaan anggota kelompok Jamaah Tabligh dari aroma minyak wangi yang dipakai, di samping simbolsimbol lain yang menjadi ciri khas mereka.

Memakai wewangian di kalangan anggota Jamaah Tabligh merupakan tradisi yang ditekankan, didasari oleh keyakinan bahwa melaksanakanya adalah ibadah dan hukumnya sunnah. Dalam pandangan mereka seorang Muslim lakilaki disunahkan memakai wewangian pada saat akan pergi ke masjid atau ke tempat lainnya. Akan tetapi bagi seorang Muslim perempuan diharamkan untuk memakai wewangian pada saat keluar rumah. Seorang muslim perempuan dianjurkan untuk berhias dan memakai wewangian hanya untuk suami atau ketika berada di dalam rumah.

Aroma wangi identik dengan kebersihan, sementara bau yang tak sedap identik dengan sesuatu yang kotor. Dalam beberapa ayat Al-Quran dan hadits disebutkan bahwa Allah swt. adalah dzat yang baik dan menyukai kebaikan, Dia dzat yang indah dan menyukai keindahan. Menurut Jamaah Tabligh, aroma wangi dapat mendatangkan banyak manfaat, di antaranya memberikan kesegaran bagi diri sendiri dan orang lain, wewangian disukai oleh para malaikat yang menyampaikan rahmat Allah swt. kepada para manusia. Sementara bau yang tidak sedap seperti bau asap kemenyan disukai oleh para syetan dari kalangan jin yang dapat merugikan manusia.

Parfum pada umumnya menggunakan campuran alkohol sebagai bahan untuk memperkuat aroma dan media untuk menebarkan aroma wangi, penggunaan alkohol tersebut dipilih dikarenakan karakteristiknya yang mudah 
menguap. Di dalam ajaran Islam alkohol adalah zat yang dilarang untuk dikonsumsi sebagaimana tercantum di dalam ayat Al-Quran surat Al-Baqarah ayat 219 dan surat Al-Maidah ayat 90. Pada ayat tersebut Allah swt. mengharamkan minuman keras arak yang merupakan minuman beralkohol berkadar tinggi. Alasannya adalah karena arak dapat mamabukkan dan membahayakan kesehatan apabila dikonsumsi dalam jumlah di luar kewajaran.

Rasulullah di dalam satu sabdanya memperjelas hukum mengkonsumsi minuman yang mengandung alkohol, meminum alkohol banyak maupun sedikit, mabuk atau tidak tetap haram hukumnya. Dan Jamaah Tabligh menghindari pemakaian parfum yang ada alkoholnya, sebagai upaya kehati-hatian, agar tidak terjerumus kepada perbuatan yang dilarang oleh ajaran Islam. Sikap tersebut juga diambil oleh sebagian umat Islam, selain Jamaah Tabligh, seperti kebanyakan umat Islam di Timur Tengah memakai parfum tanpa alkohol dengan maksud menghindari sesuatu yang diharamkan. Fenomena ini memiliki implikasi positif terhadap tumbuhnya kreativitas usaha di bidang parfum sehingga dapat menjadi lapangan usaha bagi orang yang berminat mengembangkannya.

\section{Tradisi Makan Berjamaah}

Makan berjamaah mengandung unsur pendidikan, mampu melatih jiwa supaya memiliki sifat rendah hati. Nabi Muhammad saw. makan dengan cara seperti itu, makanan tidak banyak tersisa, karena satu sama lain berusaha membersihkan makanan yang tersisa, sehingga tidak banyak makanan yang mubazir.

Anggota Jamaah Tabligh terdiri dari berbagai kalangan, status sosial, tingkat pendidikan, dan profesi. Di antara mereka ada pekerja kasar, pegawai negeri, pegawai swasta, pedagang, dan sebagainya. Pada saat "keluar" untuk berdakwah mereka makan bersama dalam satu nampan tanpa merasa canggung. Berkah atau barokah menjadi istilah yang sering digunakan dalam percakapan di kalangan umat Muslim, maksudnya adalah bertambahnya kebaikan dan rahmat Allah swt.

Berbagai kelebihan makan berjamaah tanpa menggunakan sendok, menurutnya cara makan tersebut dapat menjadi media untuk menyatukan hati dan benar-benar berangkat dari keyakinan kepada Allah dan Rasul-Nya, dan para jamaah Tabligh menyebutkan cara makan tersebut yang terbaik. Mereka menilai dengan perspektif keimanan, yang menurutnya lebih penting untuk dikedepankan dari nalar dan logika manusia.

Kesan yang muncul dari cara makan tersebut menggambarkan kesederhanaan kelompok Jamaah Tabligh dalam makan dan minum, seperti disebutkan di dalam Al-Quran Surat Al-A'raf ayat 31, Makanlah dan minumlah kalian dan janganlah kalian berlebihan, sesunggubnya Allab tidak menyukai orang-orang yang berlebihan. Jamaah Tabligh selalu berusaha mengamalkan segala syariat Islam yang sudah diketahui, termasuk adab sehari-hari seperti makan, minum, berpakaian, bahkan cara tidur pun berusaha mengikuti tuntunan yang disyariatkan. 
Sendok yang biasa dipergunakan sebagai alat makan secara sepintas tampak lebih bersih daripada tangan, tetapi apabila diperhatikan secara mendalam sebetulnya tangan dapat lebih bersih dibanding sendok. Kebersihan tangan dapat dikontrol oleh diri sendiri, berbeda dengan sendok yang tidak diketahui kebersihannya.

Cara makan yang dilakukan oleh kelompok Jamaah Tabligh merupakan kebiasaan yang jarang dilakukan oleh masyarakat Indonesia. Kebiasaan ini mereka lakukan khususnya ketika sedang melaksanakan kegiatan khuruj; yaitu kegiatan keluar ke suatu masjid untuk melakukan ta'lim dan tabligh kepada masyarakat sekitar masjid. Cara makan seperti ini juga mereka lakukan ketika sedang berada di rumah bersama seluruh angota keluarga.

Kegiatan makan ini menjadi media bagi anggota Jamaah Tabligh untuk mempererat hubungan silaturahmi di antara anggota kelompok. Makan dalam satu nampan secara bersama-sama menghadirkan suasana yang akrab di antara anggota Jamaah Tabligh, tidak memandang perbedaan status sosial.

Tradisi makan berjamaah di kalangan Jamaah Tabligh sebagai upaya untuk menjaga kekompakan dan kedekatan sehingga komunikasi berjalan kondusif di antara jamaah. Di mana mereka makan di tempat yang layak secara bersamasama tanpa ada sekat sehingga membuat mereka semakin dekat. Pentingnya tempat makan Jamaah Tabligh ini mempengaruhi gaya komunikasi di antara anggota keluarganya. Octavianti dalam penelitiannya menyatakan bahwa karakteristik ruang di rumah tidak layak huni berkontribusi pada proses komunikasi yang terjadi di antara sesama anggota keluarga (Octaviani, 2016: 10). Begitu pun ketika makan di tempat yang tidak layak, maka berkontribusi pada proses komunikasi di antara sesama Jamaah Tabligh.

\section{Jabat Tangan sebagai Tanda Keakraban}

Dilihat dari artinya, bersalaman berasal dari kata salam yang artinya selamat, sentosa, sejahtera. Di dalam ajaran Islam, jabatan tangan tidak saja tradisi, tetapi memiliki makna religius yang bernilai ibadah, seperti disabdakan oleh Rasul: "Dari Bara bin Azib bahwa Nabi saw. bersabda: "Tidaklah dua orang muslim yang berjumpa lalu berjabat tangan, kecuali dosa kedua-duanya diampuni oleh Allah swt. sebelum keduanya berpisab" (Diriwayatkan oleh Ahmad, At-Tirmidzi, Abu Dawud dan Ibnu Majah).

Menurut hadits tersebut jabatan tangan memiliki nilai ibadah apabila dilakukan dengan tulus dan ikhlas, Allah swt. akan menghapus dosa orang yang bersalaman. Imam mengatakan bersalaman itu suatu kebaikan, dan kebaikan memiliki nilai ibadah.

Menurut jamaah kalau berjabat tangan asal menempel, sambil lalu, tanpa ekspresi akan terkesan formalitas saja. Cara berjabat tangan seperti itu tidak akan menimbulkan efek positif pada pelakunya, lagi pula teu pararugub (rasanya tidak mantap), dan tidak mengikuti ketentuan sunnah Rasul.

Jabatan tangan termasuk ke dalam perilaku menyentuh dalam kajian 
komunikasi nonverbal, ada beberapa kategori sentuhan; fungsional-profesional, sosial-sopan, persahabatan-kehangatan, cinta-keintiman, dan sentuan yang bermakna seksual. Sentuhan-sentuhan tersebut memiliki makna dingin, menunjukkan kesopanan, keakraban, keterikatan emosional, dan cinta atau keintiman. Jabatan tangan dalam konteks komunikasi nonverbal termasuk jenis sentuhan untuk menunjukkan kesopanan. Makna jabatan tangan memiliki tergantung pada budaya dan konteks; bisa berarti basa-basi, penghormatan, ungkapan rasa senang atas sebuah pertemuan, ucapan selamat, dan sebagainya. Sentuhan juga memiliki makna ritualistik seperti menurut DeVito (1997:204), bahwa sentuhan ritualistik terpusat pada salam dan perpisahan. Menjabat tangan untuk mengatakan "halo" atau "sampai jumpa" merupakan contoh yang jelas dari sentuhan ritualistik. Sentuhan ritualistik juga meliputi pelukan, ciuman atau meletakkan lengan anda di bahu orang lain ketika anda memberi salam atau mengucapkan selamat berpisah.

Jabatan tangan di kalangan Jamaah Tabligh memiliki makna sebagai simbol keakraban di antara sesama anggota dan ungkapan penghormatan dan rasa saling menyayangi dengan sesama muslim. Cara bersalaman Jamaah Tabligh tidak sekedar menyentuh tetapi selalu erat, ini menjadi salah satu ciri khas Jamaah Tabligh; jabatan tangan yang erat menandakan perhatian yang besar kepada orang yang diajak bersalaman, menunjukkan ketertarikan, rasa senang atas kehadiran saudaranya yang sesama muslim, ungkapkan kegembiraan atas pertemuan tersebut. Cara tersebut adalah sunnah Rasul, karena beliau mencontohkan kepada umatnya untuk bersalaman dengan erat dan tidak melepaskannya sebelum orang yang diajak bersalaman lebih dulu melepaskan.

Seorang yang berjabat tangan dengan saudaranya yang sebelumnya memiliki perasaan negatif atau sedang dalam masalah antara keduanya, akan berkurang perasaan negatif tersebut dengan saling saling memegang telapak tangan keduanya dengan erat.

Jabatan tangan yang baik menurut Islam adalah yang dilakukan dengan tulus ikhlas, jabatan tangan yang seperti itu yang menurut Nabi Muhammad saw. akan menimbulkan rahmat dan kasih sayang Allah swt. Ketulusan dan keikhlasan seseorang antara lain dapat dilihat dari ekspresi wajah ketika bersalaman; seorang yang bersalaman dengan memberikan senyum yang tulus bukan kamuflase akan memberikan pengaruh positif bagi orang yang diajak bersalaman. Oleh karena itu disunnahkan untuk menunjukkan ekspresi wajah tulus berupa senyuman, karena bagi seorang muslim senyuman merupakan salah satu bentuk shadaqah kepada orang lain.

Berjabat tangan merupakan tradisi yang biasa dilakukan oleh hampir seluruh bangsa di dunia, biasanya dilakukan pada saat bertemu baik dalam suasana formal maupun informal. Agama Islam memandang bersalaman sebagai satu amalan yang bernilai ibadah dan memiliki berbagai keutamaan, diantaranya menjadi sebab tejadinya pengampunan dosa, baik bagi orang yang mengajak 
bersalaman maupun yang diajak bersalaman, sebagaimana sabda Rasul saw. "Dari Bara bin Azib bahwa Nabi saw. bersabda: "tidaklah dua orang muslim yang berjumpa lalu berjabat tangan, kecuali dosa kedua-duanya diampuni oleh Allah swt. sebelum keduanya berpisab" (Diriwayatkan oleh Ahmad, At-Tirmidzi, Abu Dawud dan Ibnu Majah).

Bersalaman antara dua orang muslim menjadi salah satu faktor untuk terciptanya rasa saling menyayangi antara keduanya dan menjadi sebab datangnya rahmat Allah swt., sebagaimana digambarkan dalam sabda Nabi Muhammad saw.: Dari Umar, Nabi saw. Bersabda: "Apabila bertemu dua orang muslim lalu memberi salam salah seorang dari keduanya kepada kawannya tersebut, maka yang paling dicintai adalah yang paling terbaik senyumnya kepada kawannya. Apabila mereka berjabat tangan, maka Allah swt. akan memberikan kepada mereka berdua seratus rabmat, sembilan pulub bagi yang memulai, dan sepulub bagi yang disalami."

Bersalaman akan menghilangkan pikiran negatif, mencairkan suasana hati yang berprasangka buruk, menyimpan perasaan dengki pada diri seseorang baik yang mengajak bersalaman maupun yang diajak, sebagaimana disabdakan Rasul saw. Dari Atha Al-Khurasani bahwa Rasulullah saw. bersabda: "Berjabat tanganlah kalian, niscaya perasaan dengki akan hilang, dan saling memberi hadiah kalian, niscaya kalian akan saling mencintai dan terhindar dari rasa permusuban”.

Banyak cara dan gaya berjabat tangan, ada di antara orang yang berjabat tangan dengan memegang erat tangan orang yang diajak bersalaman penuh semangat dan kehangatan, ada yang bersalaman dengan biasa-biasa saja tanpa dibarengi dengan banyak ekspresi, ada pula yang bersalaman sekedar menyentuh sambil berlalu.

Mengenai salaman ini, Al-Selebessy (2004:57-64) mengemukakan tata cara bersalaman sesuai dengan tuntunan sunnah Rasulullah saw., yaitu berjabat tangan dengan kanan dan saling menggenggam dengan erat, bukan menyentuh sebagian saja, dan tidak melepaskan tangan sebelum orang yang disalami hendak melepaskan tangannya, sebagaimana sabda Rasul saw. Dari Nafi', dia berkata: "Nabi Mubammad saw. apabila mengucapakn salam kepada seseorang, beliau menjabat tangan orang itu, beliau tidak melepaskan tangan orang itu sebelum orang itu yang melepaskan tangan Nabi saw" (HR. At-Tirmidzi dan Ibnu Majah).

Kemudian sebelum berjabat tangan atau bersalaman, ucapkanlah bamdalah dan istighfar, sesuai sabda Nabi Muhammad saw. "Apabila berjumpa dua orang muslim lalu berjabat tangan, seraya keduanya bertabmid (mengucapkan alhamdulillab) dan memohon maghfirah maka dosa keduanya akan diampuni oleh Allah swt" (HR Abu Dawud).

Mengenai jabat tangan yang erat dan kuat seperti yang dilakukan Jamaah Tabligh ini menandakan bahwa jabat tangan sedikit banyak bisa diketahui sifat dan maksud orang tersebut. Dengan jabat tangan juga secara tidak langsung bersentuhan. Dan sentuhan merupakan hal yang sehat dan menenangkan. Dan . sentuhan bisa merangsang perasaan dan membutuhkan tanggapan (Della, 2014: 123). 
Hal yang sama juga dikatakan Rizal bahwa sentuhan merupakan alat komunikasi yang sangat kuat, dapat menimbulkan reaksi positif, namun juga negatif tergantung dari individu yang terlibat dalam proses komunikasi dan lingkungan di sekeliling berlangsungnya komunikasi. Sentuhan dapat menunjukkan makna "saya peduli", kasih sayang, dukungan emosional, dan perhatian (2017: 59). Tidaklah heran kalau di antara Jamaah Tabligh memiliki ikatan emosional yang kuat, dan begitu akrab satu sama lainnya karena mereka seringkali bersentuhan atau bersalaman yang kuat.

\section{Selalu Menjaga Keramahtamahan dan Keakraban}

Gagasan memuliakan orang lain atau yang dikenal dengan Ikramul Muslimin merupakan salah satu misi gerakan Jamaah Tabligh. Asas inilah yang menyebabkan para pengikut gerakan Jamaah Tabligh tampak selalu ramah, murah senyum, mudah bergaul, dan selalu menghargai orang lain. Mereka meyakini bahwa orang lain sesama Muslim adalah saudara, penghargaan kepada orang lain berarti penghargaan kepada diri sendiri, orang lain adalah objek dakwah yang senantiasa harus dihargai dan dihormati walaupun berakhlak kurang baik, tidak dibolehkan memiliki kebencian kepada orang lain sesama muslim, mereka semua saudara, hanya menurut mereka masih belum mengamalkan syariat agama.

Kebiasaan di kalangan anggota Jamaah Tabligh, selalu ramah ketika bertemu sesama Muslim, walaupun tidak saling kenal. Hampir setiap jamaah yang ditemui menampakkan wajah bersahabat dan menunjukkan rasa senang atas kedatangan mereka ketahui sebagai orang baru.

Jamaah Tabligh mengedepankan aspek persaudaraan antar sesama Muslim, setiap Muslim adalah saudara, tidak ada perbedaan di antara sesama muslim kecuali dilihat dari ketakwaan kepada Allah swt. Jamaah Tabligh merupakan asosiasi yang mengeliminir perbedaan status sosial, ekonomi, pendidikan dan sebagainya. Hal seperti digambarkan oleh Allah swt. di dalam Al-Quran bahwa orang yang paling mulia di sisi Allah adalah orang yang paling bertakwa, tidak ada keutamaan di antara sesama manusia selain karena keimanan dan ketakwaan.

Karakteristik hubungan di kalangan Jamaah Tabligh ditandai dengan suasana keakraban baik di kalangan sesama anggota jamaah maupun dengan orang lain. Suasana tersebut senantiasa tampak dalam setiap aktivitas, khususnya ketika sedang melaksanakan kburuj fi sabilillab satu sama lain saling membantu dalam menyelesaikan pekerjaan dan saling membahu dalam memikul tanggung jawab kelompok.

Suasana keakraban tampak pada saat melaksanakan ta'lim dan bayan, setiap jamaah duduk bersimpuh atau duduk bersila merapatkan barisan, hampir tidak ada celah antara satu jamaah dengan jamaah lain. Suasana tersebut jarang sekali terlihat pada kegiatan pengajian selain di kalangan Jamaah Tabligh. Cara duduk seperti itu menjadikan hubungan di antara sesama anggota Jamaah Tabligh menjadi lebih mudah saling kenal dan lebih akrab. Duduk merapatkan barisan 
Imron Rosyidi \& Encep Dulwahab

menunjukkan semangat yang tinggi dalam melaksanakan ta'lim dan menunjukkan antusiasme terhadap setiap materi yang disampaikan oleh narasumber.

Sikap ramah dan akrab menjadi ciri khas Jamaah Tabligh. Sikap tersebut merupakan cerminan akhlak mulia yang dicontohkan oleh Nabi Muhammad saw. Di dalam agama Islam aspek akhlak menempati porsi yang besar jika ditinjau dari muatan pahala yang dijanjikan oleh Allah swt. Nabi Muhammad saw. diutus ke muka bumi membawa misi penyempurnaan akhlak, dan agama Islam merupakan agama yang berorientasi pada dua aspek, yaitu aspek ritual dan aspek sosial. Dari kedua aspek tersebut aspek sosial lebih menjadi prioritas, hal ini digambarkan secara eksplisit dalam beberapa ayat Al-Qur'an dan Hadits.

Sikap ramah dan akrab Jamaah Tabligh yang selalu dijaga ini merupakan salah satu ikhtiar agar memiliki penilaian positif dari masyarakat di mana mereka berdakwah (khuruj). Karena keramahan dan keakraban akan menjadi strategi efektif dalam mendekatkan diri dengan masyarakat. Sebagaimana dikatakan Mirawati dan kawan-kawan bahwa bahasa nonverbal yang terutama perlu diawasi adalah kinesik, proksemik, kronemik, dan terutama adalah ekspresi wajah (2012: 212). Dengan ramah maka akan memperlihatkan ekspresi wajah yang lembut, halus, sopan dan menenangkan orang lain.

\section{Duduk Bersimpuh agar Tahan Lama}

Cara duduk bersimpuh memiliki kelebihan dan keuntungan tersendiri dibanding cara duduk lainnya seperti bersila. Duduk bersimpuh membuat seseorang dapat lebih lama duduk dan tidak membuat cepat lelah dibanding duduk bersila. Karena dengan duduk bersimpuh, energi negatif akan tersalurkan ke bumi melalui kedua ujung kaki, sehingga seseorang akan merasa lebih nyaman dapat bertahan duduk dalam jangka waktu yang lama.

Agama Islam mengajarkan cara duduk dalam praktek shalat yang terdiri dari berbagai gerakan yang unik yang terdiri dari gerakan berdiri, membungkukkan badan (ruku), mencium tanah (sujud), dan duduk (tasyahud) dengan cara bersimpuh, melipat kedua kali, menjadiakan keduanya sebagai penopang paha. Cara duduk dalam shalat tersebut memiliki filosofi cara duduk yang bernilai tinggi terutama dari sisi kesehatan tubuh.

Kebiasaan Jamaah Tabligh memakai pakaian, cara bersalaman, cara duduk,

cara makan, semuanya didasari oleh keyakinan bahwa agama Islam mengajarkannya demikian, di tambah lagi sebagaimana dicontohkan oleh Nabi Muhammad saw. dan para sahabatnya. Sebagai pengikut Muhammad saw., Jamaah Tabligh diharuskan mengikuti segala tata cara hidup yang dicontohkan olehnya. Kebiasaan ini dilakukan oleh hampir seluruh Jamaah dan menjadi ciri khas kelompok tersebut.

Jamaah Tabligh memiliki pemahaman sama dengan gerakan salafy atau di Indonesia terkenal dengan Laskar Jihad yang dipimpin oleh Ja'far Umar Thalib. Pada aspek penampilan fisik terdapat kesamaan antara kedua kelompok tersebut, 206

Communicatus: Jurnal Ilmu Komunikasi 1(2) (2017) 191-208 
adapun yang membedakannya ciri yang membedakan antara lain pada sikap yang ditampilkan oleh kedua gerakan tersebut, Jamaah Tabligh lebih toleran dalam memandang perbedaan-perbedaan di antara umat muslim, mereka lebih ramah kepada sesama muslim. Jamaah Tabligh memegang prinsip ikramul muslimin yaitu keharusam memuliakan sesama umat Islam.

Para Jamaah Tabligh dengan melakukan komunikasi non verbal ketika berkomunikasi denan sesama jamaah atau dengan masyarakat sekitar, memudahkannya dalam berkomunikasi. Sebagaimana dikatakan Nisawatun Ulmi bahwa dengan adanya komunikasi non-verbal, ia sebenarnya lebih memberi penekanan, pengulangan, melengkapi dan menggantikan komunikasi verbal sehingga ia lebih mudah ditafsirkan (dalam Ibrahim dkk., tt:111).

Aktivitas Jamaah Tabligh yang memiliki ciri dan gaya berbeda dibanding jamaah lainnya, merupakan upaya menurut Kuswarno yakni sebagai pengelolaan kesan melalui simbol verbal dan nonverbal. Sementara kalau menggunakan perspektif dramaturgis yang dikemukakan Goffman dengan impression managementnya, maka aktivitas Jamaah Tabligh ini tidak ubahnya sedang melakukan sebuah pertunjukan. Para aktor, dalam hal ini Jamaah Tabligh, yang mencoba membangun kesan tertentu, dengan tujuan tertentu pula (dalam Muhaemin, 2017: 351-352).

\section{PENUTUP}

Berdasarkan paparan di atas bahwa pada Jamaah Tabligh memiliki pesan-pesan nonverbal yang kuat dalam setiap komunikasinya. Baik dengan sesama jamah, ataupun dengan masyarakat sekitar ketika Jamaah Tabligh sedang melakukan khuruj. Pesan-pesan nonverbal Jamaah Tabligh tersebut sekaligus sebagai penegas identitasnya sebagai seorang muslim, sehingga orang bisa membedakan antara Jamaah Tabligh atau bukan. Dan komunikasi nonverbal tersebut merupakan strategi dakwah Jamaah Tabligh bahwa salah satu manifestasi akan keyakinan sebagai muslim, harus mengamalkan ajaran agama Islam dan kecintaannya pada Rasulullah saw dalam hal berpenampilan, berinteraksi, dan tata cara dalam kehidupan sehari-hari. Dari hasil penelitian ini pula setidaknya membuka peluang untuk penelitian berikutnya tentang bagaimana komunikasi dakwah Jamaah Tabligh, karena sampai sekarang Jamaah Tabligh masih bisa bertahan.

\section{DAFTAR PUSTAKA}

Al-Fauzan, S.B.F. (1999). Loyalitas dalam Islam. Al-Qassem: Akafa Press. Al-Selebesi, A.A.A. (2004). Fadhilah Salam dan Berjabat Tangan. Bandung: Al Ishlash Press.

De Vito, J. A. (1997). Human Commuication. Jakarta: Professional Books. 
Imron Rosyidi \& Encep Dulwahab

Della, P.O. (2014). Penerapan Metode Komunikasi Non Verbal Yang Dilakukan Guru Pada Anak-Anak Autis Di Yayasan Pelita Bunda Therapy Center Samarinda dalam Jurnal Ilmu Komunikasi, 2 (4). 114 -128.

Ibrahim, N. A. N \& Mahbob, M. H. \& Ahmad, A.L. (tt). Kepentingan Komunikasi Non Verbal Dalam Organisasi dalam Journal of Social Sciencies and Humanities, 15 (5). 107-116.

Kusumawati, T.I. (2016). Komunikasi Verbal dan Nonverbal dalam Jurnal AlIrsyad, 1 (6), 140-151.

Mirawati. I, \& Erlandia, D.R., \& Octavianti, M. (2012). Komunikasi Nonverbal Penyontek: Studi Terhadap Cara Mendeteksi Perilaku Menyontek Oleh Para Pengawas Ujian dalam Jurnal Ilmu Komunikasi, 8 (2). 212-223.

Muhaemin, E. (2017). Dakwah Digital Akademisi Dakwah. dalam Ilmu Dakwah: Academic Journal for Homiletic Studies, 11(2). 341-356.

Mulyana, D. (2000). Ilmu Komunikasi Suatu Pengantar. Bandung: PT Remaja Rosdakarya.

Octavianti, M. (2016). Komunikasi Nonverbal Proksemik di Rumah Tidak Layak Huni dalam Jurnal Kajian Komunikasi, 4 (1).10-27.

Rafiudin \& Djalil, M.A. (1997). Prinsip dan Strategi Dakwah. Bandung: CV Pustaka Setia.

Rahman, T. (2016). Komunikasi Dakwah Pesantren Tradisional dalam Jurnal Ilmu Dakwah: Academic Journal for Homiletic Studies, 10 (2). 375-397.

Rizal, M. (2017). Impression Management Verbal dan Non Verbal Pekerja Seks Komersial di Kelurahan Talise dalam Jurnal Online Kinesik, 4 (2). 57-68.

Sentosa, A.T. (2015). Pola Komunikasi dalam Proses Interaksi Sosialdi Pondok Pesantren Nurul Islam Samarinda dalam Jurnal Ilmu Komunikasi, 3(3):491503. 